\title{
A systematic study of Girdin on cell proliferation, migration and angiogenesis in different breast cancer subtypes
}

\author{
HONGBIN WANG, JIAJUN ZHANG, MING ZHANG, LI WEI, HONG CHEN and ZHIGAO LI \\ Department of Breast Surgery, Harbin Medical University Cancer Hospital, Harbin, Heilongjiang 150081, P.R. China
}

Received February 3, 2016; Accepted February 20, 2017

DOI: $10.3892 / \mathrm{mmr} .2017 .6971$

\begin{abstract}
Breast cancer has one of the highest incidences in females worldwide. Girdin is a novel actin-binding protein, that induces cell migration and angiogenesis. However, a systematic study of Girdin function in distinct subtypes of breast cancer has not been reported to date. Therefore, the present study aimed to investigate the role of Girdin on cell proliferation, migration and angiogenesis in different subtypes of breast cancer. For this purpose, the breast epithelial MCF-7, breast ductal T47D and breast metastatic MDA-MB-231 cancer cell lines were selected. Girdin small interfering RNA (siRNA) was transfected into MCF-7, T47D and MDA-MB-231 cells. Girdin knockdown suppressed cell viability and migration in the different cancer cells tested. Girdin knockdown also suppressed mRNA expression of vascular endothelial growth factor (VEGF), and activation of phosphatidyl inositol 3-kinase (PI3K) and RAC- $\alpha$ serine/threonine-protein kinase (Akt) in the subtypes tested. In conclusion, these data indicate that Girdin knockdown suppressed cell viability and migration and may suppress angiogenesis via the PI3K/Akt signaling pathway, in various breast cancers subtypes. The present study therefore suggests a role for Girdin as a novel therapeutic target for breast cancer, independent of subtype.
\end{abstract}

\section{Introduction}

Breast cancer has one of the highest incidences in females worldwide, and it is the primary cause of mortality in female patients with cancer (1). At present, various breast cancer treatment methods have limitations, for example; surgery does not preclude hematopoietic or lymphatic dissemination leading to distant metastasis (2). A major advancement in the treatment of breast cancer has been targeted therapy (3). Therefore, research

Correspondence to: Dr Zhigao Li, Department of Breast Surgery, Harbin Medical University Cancer Hospital, 6 Baojian Road, Harbin, Heilongjiang 150081, P.R. China

E-mail: lizhigao2014@sina.com

Key words: Girdin, MCF-7, T47D, MDA-MB-231, phosphatidyl inositol 3-kinase, RAC- $\alpha$ serine/threonine-protein kinase focusing on the molecular mechanisms of the development and metastasis of breast cancer is required.

Girdin is a novel actin-binding protein [a structural schematic which was first published by Jiang et al (4) in 2008, is depicted in Fig. 1], that induces cell migration and angiogenesis (5). Cell migration is a physiological activity of cells; however, is also involved in the pathological processes of cancer invasion and metastasis (6). A previous study has demonstrated that Girdin promotes DNA synthesis in tumor cells and inhibits their apoptosis (5). Girdin has also been demonstrated to induce migration and invasion of endothelial cells and thus promote angiogenesis (7). However, a systematic study of the role of Girdin in distinct subtypes of breast cancer has not been reported to date. Therefore, three cell lines, representing different subtypes of breast cancer, were selected for use in the present study: The epithelial MCF-7; the ductal T47D; and the metastatic MDA-MB-231 breast cancer cell lines. The present study aimed to investigate the role of Girdin on cell proliferation, migration and angiogenesis in the various subtypes of breast cancer cells, and potentially provide insights on novel therapeutic targets for breast cancer.

\section{Materials and methods}

Cell culture. MCF-7, T47D and MDA-MB-231 cells were purchased from the American Type Culture Collection (Manassas, VA, USA). The present study was performed in accordance with the Experimental Guidelines of Harbin Medical University (Harbin, China) and ethical approval was obtained from Harbin Medical University. MCF-7 cells were cultured in RPMI 1640 medium (Sigma-Aldrich; Merck KGaA, Darmstadt, Germany) supplemented with $10 \%$ fetal bovine serum (FBS) (Sigma-Aldrich; Merck KGaA). T47D and MDA-MB-231 cells were cultured in Dulbecco's Modified Eagle's Medium (DMEM; Sigma-Aldrich; Merck KGaA) supplemented with $10 \%$ FBS. All cells were cultured with $100 \mathrm{U} / \mathrm{ml}$ penicillin and $100 \mathrm{mg} / \mathrm{ml}$ streptomycin (Gibco; Thermo Fisher Scientific, Inc., Waltham, MA, USA) in an incubator with $5 \% \mathrm{CO}_{2}$ at $37^{\circ} \mathrm{C}$.

Small interfering RNA (siRNA) transfection. Girdin siRNA (sc-94984) and non-targeting negative control siRNA (SIC002) were purchased from Santa Cruz Biotechnology, Inc. (Dallas, TX, USA) and GenePharma Co., Ltd. (Shanghai, China) respectively. Transfection was performed as described 
previously (8). Cells were seeded into 6-well plates at a density of $1 \times 10^{5}$ cells/well and grown to $60-80 \%$ confluency prior to transfection. siRNAs were transfected into cells using siRNA Transfection Reagent (Santa Cruz Biotechnology, Inc.), according to the manufacturer's protocol. Cells were incubated for a further $48 \mathrm{~h}$ following transfection and subsequently used for experiments.

Reverse transcription-semi-quantitative polymerase chain reaction $(R T-s q P C R)$. Total RNA was extracted by TRIzol (Sigma-Aldrich; Merck KGaA) and relative mRNA was normalized to $18 \mathrm{~S}$ ribosomal RNA. The following primers (Hokkaido System Science Co. Ltd, Sapporo, Japan) were used: Girdin, forward 5'-CCAGGCATGAAGCGAACA-3' and reverse 5'-CGAGCATCCGAAAGCAAAT-3'; vascular endothelial growth factor (VEGF), forward 5'-TTGCCTTGC TGCTCTACCTC-3' and reverse 5'-AAATGCTTTCTCCGC TCTGA-3'; and 18S, forward 5'-GTAACCCGTTGAACC CCATT-3' and reverse 5'-CCATCCAATCGGTAGTAGCG-3'. Reverse transcription was performed using a Transcriptor First Strand cDNA Synthesis kit (Roche Applied Science, Madison, WI, USA). A total of 200 ng RNA was used as input for the $\mathrm{RT}$ reaction, and $2 \mu \mathrm{l}$ input cDNA from the RT product was used for the sqPCR. PCR was performed using SYBR Premix Ex Taq II (Takara Bio, Inc., Otsu, Japan) and the ABI 7300 Fast real-time PCR system (Applied Biosystems; Thermo Fisher Scientific, Inc.). The thermocycling conditions were: Holding stage $95^{\circ} \mathrm{C}$ for $30 \mathrm{sec}(1$ cycle $)$ and cycling stage $95^{\circ} \mathrm{C}$ for $3 \mathrm{sec}$ and $60^{\circ} \mathrm{C}$ for $31 \mathrm{sec}$ (40 cycles). Ethidium bromide (Sigma-Aidrich; Merck KGaA) was used as the agarose gel visualization reagent and ImageJ software (version 1.38e; National Institutes of Health, Bethesda, MD, USA) was used for the band quantification.

MTT Assay. Cell viability was determined by a colorimetric MTT assay according to the method described previously (9). Absorbance at $550 \mathrm{~nm}$ was measured using a MTP-800 microplate reader (Corona Electric, Ibaraki, Japan). Absorbance at $690 \mathrm{~nm}$ was also measured as a control, to compensate for interfering absorbance from potential cell debris or the microtiter plate. The \% of viable cells was calculated as follows: (Optical density (OD) of treated sample/OD of untreated control) x100.

Migration assay. The migration assay was performed using 48-well migration transwell chambers with polycarbonate membranes (Sigma-Aldrich; Merck KGaA), according to the method described previously (10). To prepare the migration chambers, the upper wells were coated with $0.01 \%$ collagen and incubated for $30 \mathrm{~min}$ at $37^{\circ} \mathrm{C}$. Then, the cells $\left(5 \times 10^{4}\right.$ cells/well) were seeded on the upper chamber of the transwells in RPMI 1640 medium (for MCF-7 cells) or DMEM (for T47D and MDA-MB-231 cells). DMEM with $10 \%$ fetal calf serum was added to the lower wells of the chambers as a chemoattractant. Following incubation at $37^{\circ} \mathrm{C}$ for $24 \mathrm{~h}$, the cells that had migrated to the lower surface of the filters were fixed with $4 \%$ paraformaldehyde in PBS for $10 \mathrm{~min}$ at room temperature and stained with crystal violet. Cell migration was defined as the number of cells that had migrated to the lower filter surface. Four non-overlapping fields per filter were selected and the migrated cells were counted under a microscope (Olympus
Corporation, Tokyo, Japan) at a magnification of x100. The average number of the cells from four fields was presented as the results of the migration assay.

Western blot analysis. MCF-7, T47D and MDA-MB-231 cells were lysed by lysis buffer ( $1 \mathrm{M}$ Tris- $\mathrm{HCl}, \mathrm{pH} 7.4 ; 1 \mathrm{M} \mathrm{NaCl}$; 20\% Triton X-100; 10\% SDS; and, 0.5 M EDTA; Sigma-Aldrich Merck $\mathrm{KGaA}$ ). The protein concentration was determined by Gene Spec III from Hitachi Genetic Systems (MiraiBio, Alameda, CA, USA). Electrophoresis was performed using a vertical slab $12 \%$ SDS-PAGE, as described previously (11). A total of $20 \mu \mathrm{g}$ of protein was loaded per gel lane. Protein transfer to a membrane (Immobilon ${ }^{\circledR}$-P, Merck KGaA) was performed electrophoretically, as described previously (12) with certain modifications, using a Semi Dry Electroblotter (Sartorius AG, Goettingen, Germany) for $90 \mathrm{~min}$, with an electric current of $15 \mathrm{~V}$. The membrane was treated with Block Ace ${ }^{\mathrm{TM}}$ (4\%; Bio-Rad, Hercules, CA, USA) for $30 \mathrm{~min}$ at $22^{\circ} \mathrm{C}$. Primary antibody incubations were performed using rabbit immunoglobulin (Ig) $\mathrm{G}$ antibodies against phosphatidyl inositol 3-kinase (PI3K; SAB5500162; 1:100; Sigma-Aldrich; Merck KGaA) and RAC- $\alpha$ serine/threonine-protein kinase (Akt; SAB4500797; 1:1,000; Sigma-Aldrich; Merck KGaA) in PBS containing $0.03 \%$ Tween-20 (PBST) for $1 \mathrm{~h}$ at $22^{\circ} \mathrm{C}$. Following washing in PBST, the secondary antibody incubation was performed using horseradish peroxidase-conjugated anti-rabbit goat IgG (A0545; 20 ng/ml; Sigma-Aldrich; Merck $\mathrm{KGaA}$ ) for $30 \mathrm{~min}$ at $22^{\circ} \mathrm{C}$. Following washing in PBST, the enhanced chemiluminescence (ECL) reaction was performed on the membranes using the ECL Plus Western Blotting Detection System (GE Healthcare Life Sciences, Shanghai, China). ImageJ (version 1.38e; National Institutes of Health) was used for the quantification of western blots.

Statistical analysis. The paired Student's t-test was used to analyze the data. Analyses were conducted using SPSS software (version 17.0; SPSS, Inc., Chicago, IL, USA) and data were expressed as the mean \pm standard deviation. Each experiment was repeated at least three times. $\mathrm{P}<0.05$ was considered to indicate a statistically significant difference.

\section{Results}

Girdin knockdown decreases viability in breast cancer cells. To investigate the effect of Girdin knockdown on the viability of breast cancer cells, MCF-7, T47D and MDA-MB-231 cells were seeded onto 6-well plates, grown to 60-80\% confluency, and then transfected with either a Girdin-specific siRNA or a non-specific negative control siRNA. Following $48 \mathrm{~h}$, the efficiency of Girdin siRNA knockdown was evaluated using RT-sqPCR (Fig. 2). The results demonstrated that Girdin was efficiently silenced in all three cell lines tested, compared with the control siRNA-transfected cells (Fig. 2). Cell viability was then determined by MTT assay. MCF-7, T47D and MDA-MB-231 cells demonstrated significantly suppressed viability following Girdin knockdown compared with control siRNA-transfected cells ( $\mathrm{P}<0.01$; Fig. 3 ).

Girdin knockdown suppresses migration in breast cancer cells. The migration abilities of MCF-7, T47D and MDA-MB-231 


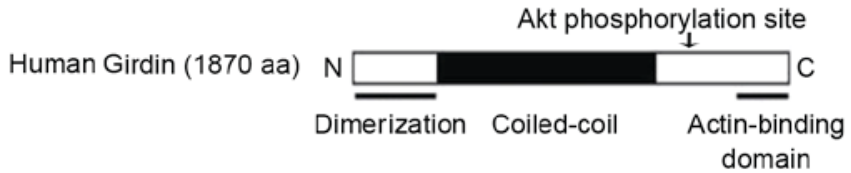

Figure 1. The structure of Human Girdin. A schematic for the proposed primary structure of the human Girdin protein. A dimerization domain is located at the N-terminus, a large coiled-coil domain at the central portion of the protein, and an actin-binding domain at the C-terminus. Akt phosphorylates Girdin at Serine 1416 (approximate location depicted by the arrow). Adapted from Jiang et al (4). Akt, RAC- $\alpha$ serine/threonine-protein kinase.

$\mathbf{A}$
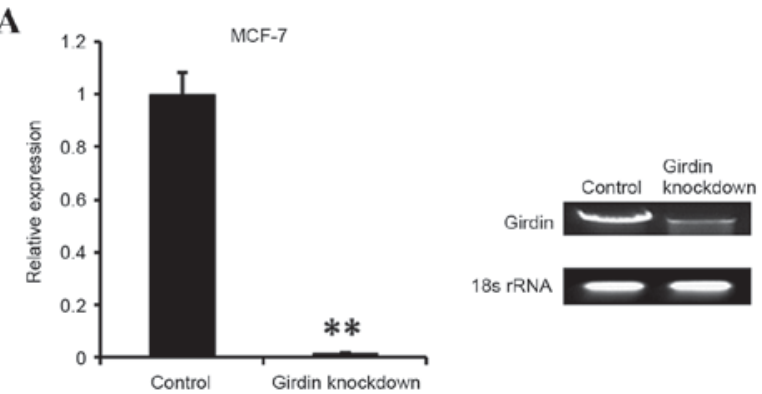

B
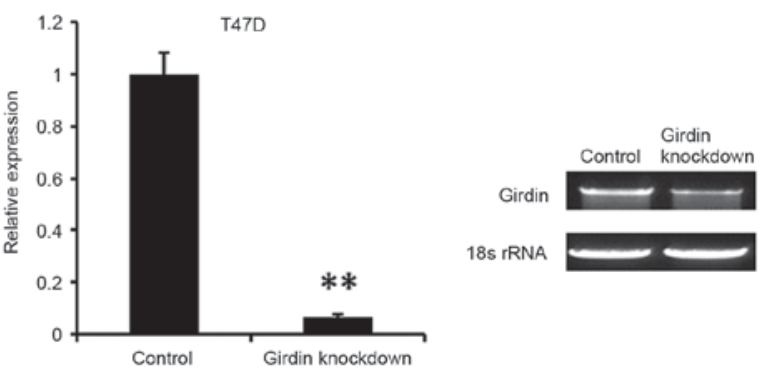

C

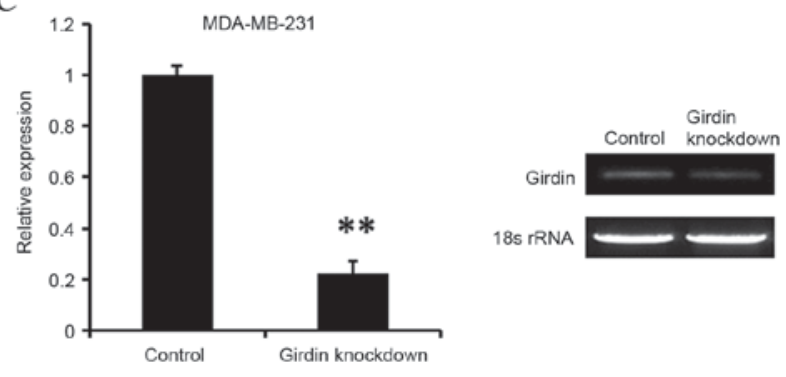

Figure 2. Efficiency of Girdin knockdown by siRNA. (A) MCF-7, (B) T47D and (C) MDA-MB-231 cells were transfected with either a Girdin-targeting siRNA or a non-targeting negative control siRNA, and mRNA expression was examined using the reverse transcription-semi-quantitative polymerase chain reaction. $18 \mathrm{~S}$ was used an internal reference for normalization. Data are expressed as the mean relative to control \pm standard deviation $(\mathrm{n}=3)$. ${ }^{* *} \mathrm{P}<0.01$ vs. control siRNA-transfected cells. siRNA, small interfering RNA; 18S, 18 S ribosomal RNA.

were examined following Girdin knockdown using a transwell chamber migration assay. Girdin deficient MCF-7, T47D and MDA-MB-231 cells exhibited significantly suppressed migration compared with the control siRNA-transfected cells $(\mathrm{P}<0.01$; Fig. 4).

Girdin knockdown suppresses VEGF expression in breast cancer cells. Breast cancer cells frequently express VEGF, an endothelial growth and chemotactic agent that promotes
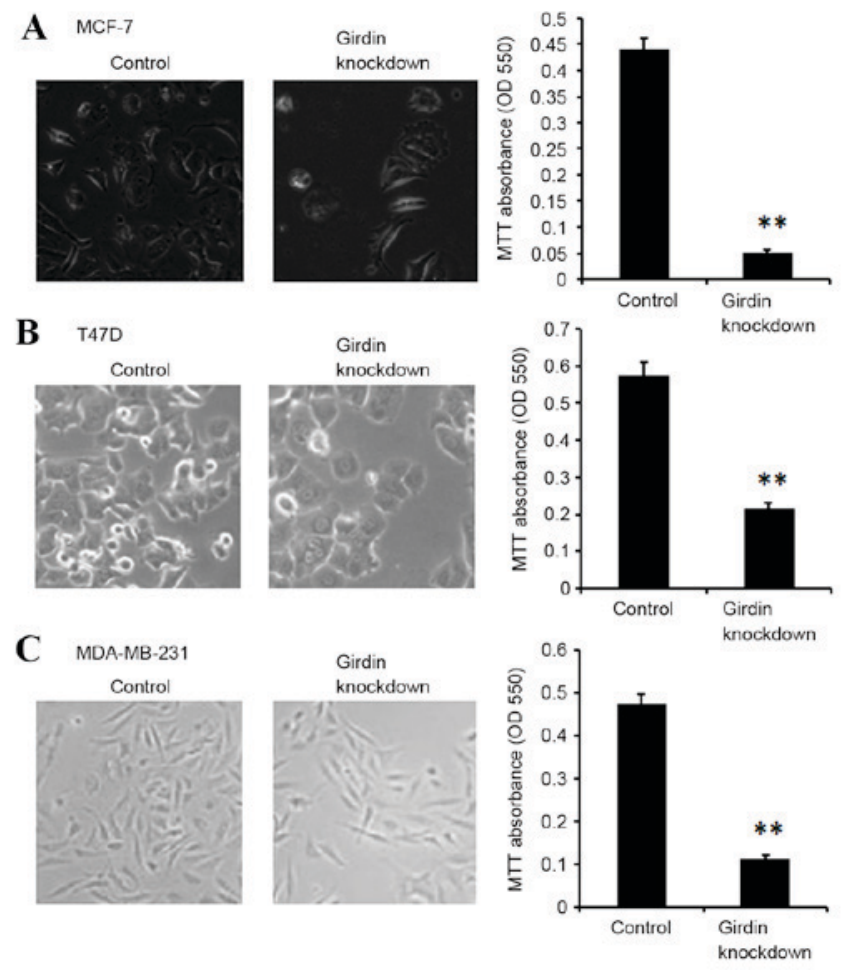

Figure 3. Effect of Girdin knockdown on viability in breast cancer cells (A) MCF-7, (B) T47D and (C) MDA-MB-231 cells were transfected with Girdin siRNA or a negative control siRNA, and $48 \mathrm{~h}$ post-transfection, viability was examined by a colorimetric MTT assay. Cells were also photographed under a phase-contrast microscope at $\mathrm{x} 400$ magnification (left panels). Data are expressed as the mean \pm standard deviation $(n=3) .{ }^{* *} \mathrm{P}<0.01$ vs. control siRNA-transfected cells. siRNA, small interfering RNA; MTT, 3-(4,5-Dimethylthiazol-2-yl)-2,5-diphenyltertrazolium bromide.

angiogenesis, and subsequently cancer metastasis. The effect of Girdin knockdown was therefore investigated on VEGF expression in breast cancer cells lines. Girdin deficient MCF-7, T47D and MDA-MB-231 cells exhibited significantly decreased VEGF mRNA expression levels, compared with control siRNA-transfected cells $(\mathrm{P}<0.01$; Fig. 5).

Effect of Girdin knockdown on PI3K and Akt expression in breast cancer cells. The protein expression levels of PI3K and Akt in Girdin deficient MCF-7, T47D and MDA-MB-231 cells were measured by western blot analysis. Expression of PI3K and Akt proteins was significantly downregulated in MCF-7, T47D and MDA-MB-231 cells following Girdin knockdown, compared with the control siRNA-transfected cells. $(\mathrm{P}<0.01$; Fig. 6).

\section{Discussion}

To the best of our knowledge, the present study demonstrated for the first time the effect of Girdin silencing on different subtypes of breast cancer. Breast cancer has one of the highest incidences in females worldwide, and it is the primary cause of mortality in female patients with cancer (1). Breast cancer has long been a leading cause of mortality in women of both developed and developing countries (13). Breast cancer is a heterogeneous disease (14). There are multiple methods of breast cancer classification. Based on tissue typing, breast cancers are 
A MCF-7 Control

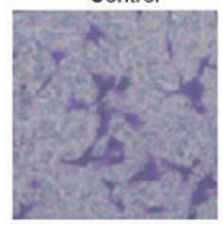

B

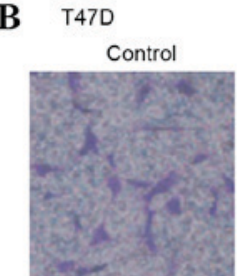

C $\quad$ MDA-MB-231 Control

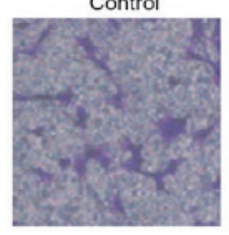

Girdin

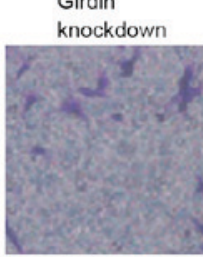

Girdin knockdown
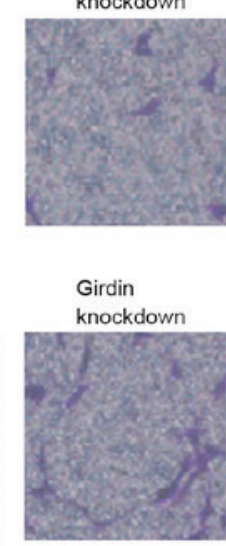
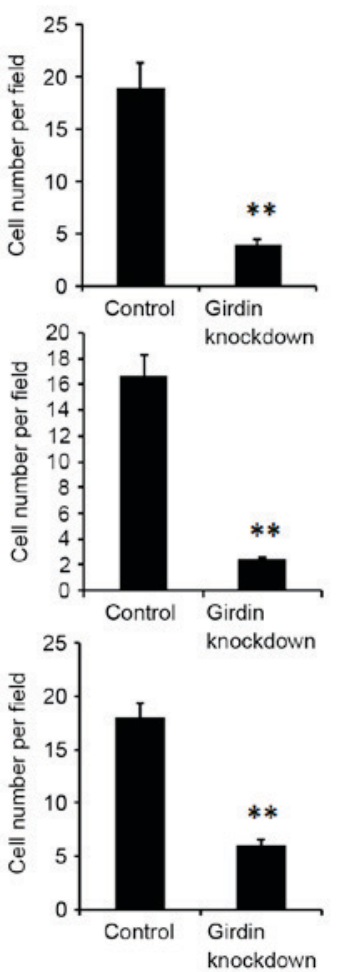

Figure 4. Effect of Girdin knockdown on migration in breast cancer cells. (A) MCF-7, (B) T47D and (C) MDA-MB-231 cells were transfected with Girdin siRNA or a negative control siRNA, and then migration ability was examined using a chamber migration transwell assay. Four non-overlapping fields per filter were selected and the migrated cells were counted. The average number of the cells from four fields was presented as the results of the migration assay. Representative images of the migrated cells at the bottom of the transwell filters are shown in the left panels (magnification, $\mathrm{x} 100)$. Data are expressed as the mean \pm standard deviation $(\mathrm{n}=3) .{ }^{* *} \mathrm{P}<0.01$ vs. control siRNA-transfected cells. siRNA, small interfering RNA.

divided to breast epithelial cancer, breast ductal carcinoma and metastatic breast cancer (15). Therefore, in the present study, three representative cell lines were selected: MCF-7, T47D and MDA-MB-231 cells, for epithelial, ductal and metastatic breast cancer respectively. Great advances in the treatment of breast cancer have come from targeted therapy (3), thus studies investigating the molecular mechanisms of breast cancer pathogenesis and metastasis are crucial for the identification of new targets.

Girdin, first discovered by Japanese scholars in 2005 (5), is a novel actin binding protein that induces cell migration and angiogenesis (16). Girdin maintains the structure of actin (17), and it induces invasion and metastasis of tumor cells and angiogenesis (4,7). The present study is consistent with these previous reports, as it demonstrated that Girdin deficiency suppressed viability and migration of different subtypes of breast cancer cells.

A previous study demonstrated that Girdin is important in vessel formation (18). VEGF is the most important pathogenic factor in vaso-proliferative disorders (19). Girdin promotes migration of VEGF-dependent endothelial cells, formation of tubular structures and remodeling of the micrangium after birth $(5,7)$. In the present study, VEGF mRNA expression was demonstrated to be significantly decreased in Girdin deficient MCF-7, T47D and MDA-MB-231 cells compared with the control siRNA-transfected cells, suggesting that

A
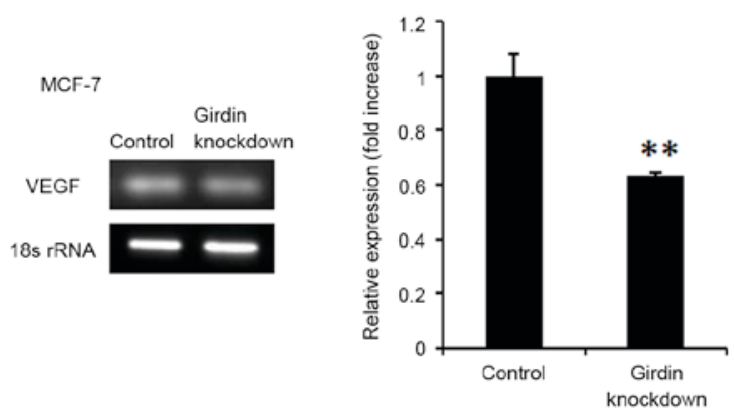

B
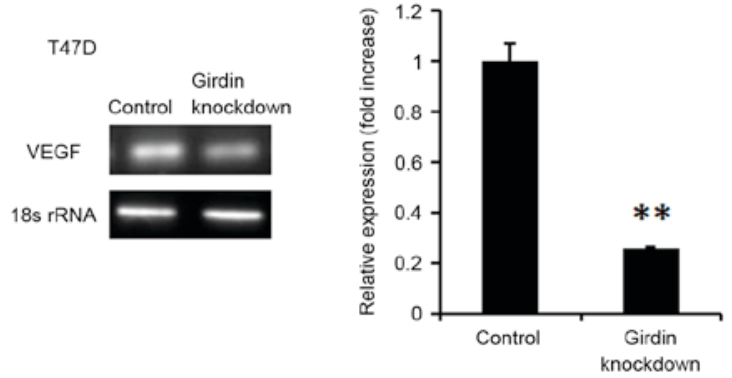

C
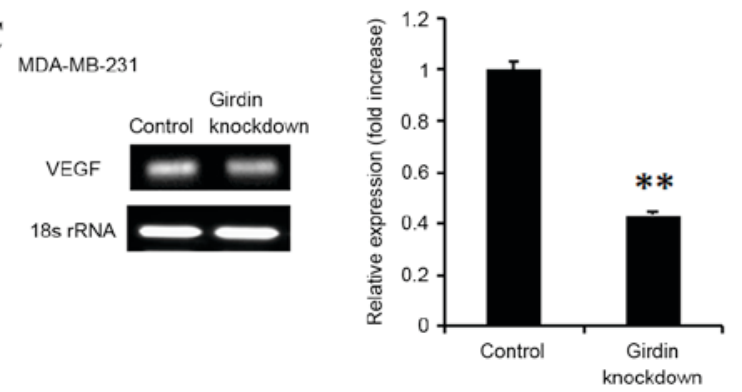

Figure 5. Effect of Girdin knockdown on VEGF expression in breast cancer cells. (A) MCF-7, (B) T47D and (C) MDA-MB-231 cells were transfected with Girdin siRNA or a negative control siRNA, and then VEGF mRNA expression levels were examined using the reverse transcription-semi-quantitative polymerase chain reaction. $18 \mathrm{~S}$ was used an internal reference for normalization. Data are expressed as the mean \pm standard deviation $(n=3) .{ }^{* *} \mathrm{P}<0.01$ vs. control siRNA-transfected cells. VEGF, vascular endothelial growth factor; siRNA, small interfering RNA; 18S, 18S ribosomal RNA.

Girdin may be important in angiogenesis of breast tumors as well.

PI3K phosphorylates phosphatidylinositol lipids in response to various growth factors (20). The PI3K/Akt signaling pathway is important in modulating cell growth, cell survival and cytoskeletal rearrangement (21). Since cancer cell proliferation and migration is regulated by the PI3K/Akt signaling pathway $(22,23)$, the present study aimed to further investigate the association between Girdin and PI3K/Akt. PI3K and Akt protein expression levels were significantly decreased in Girdin deficient MCF-7, T47D and MDA-MB-231 cells compared with the control siRNA-transfected cells. The present data demonstrated that Girdin knockdown suppressed viability, migration and angiogenesis in distinct subtypes of breast cancer, potentially via the PI3K/Akt signaling pathway.

According to the model described in Fig. 7, Girdin knockdown suppressed cell viability, migration and angiogenesis in different subtypes of breast cancers, including breast epithelial, breast ductal and metastatic breast cancer, by downregulating expression of PI3K and Akt. A previous study has indicated 


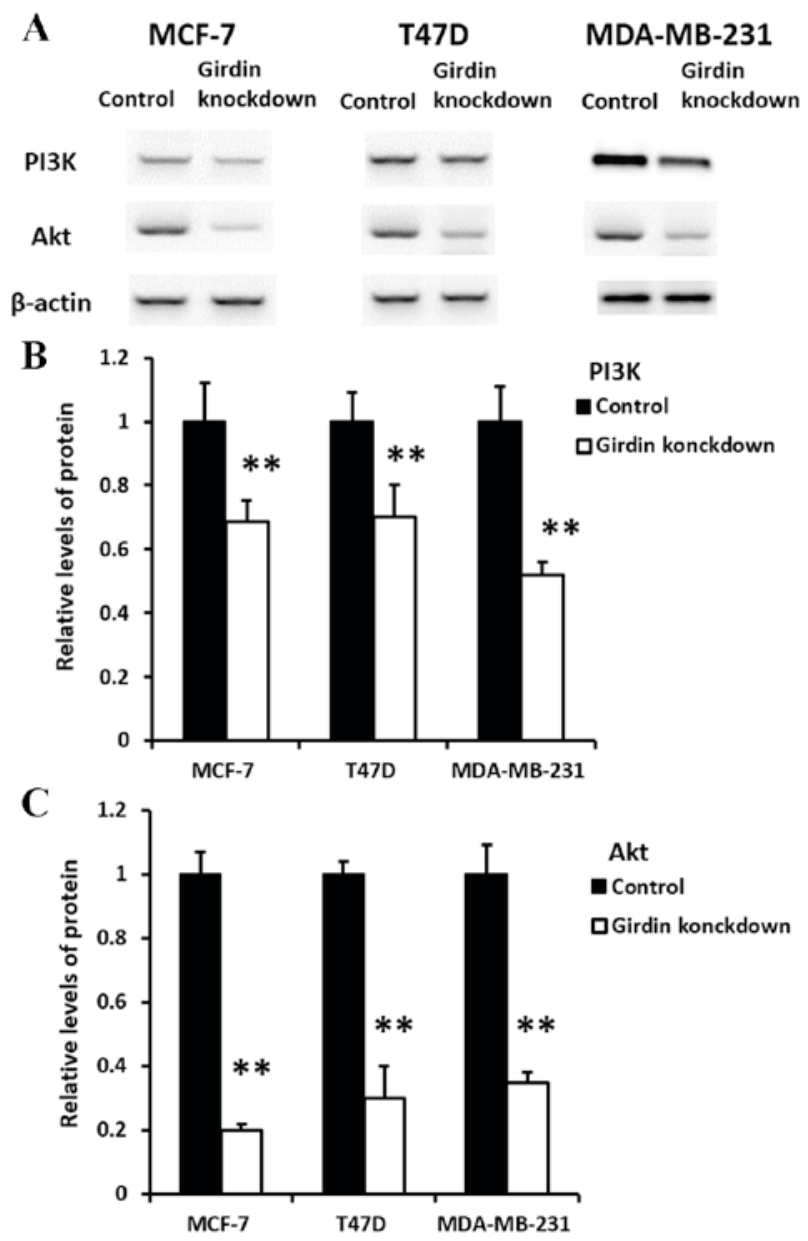

Figure 6. Effect of Girdin knockdown on protein expression of PI3K and Akt. MCF-7, T47D and MDA-MB-231 cells were transfected with Girdin siRNA or a negative control siRNA, and then PI3K and Akt protein expression levels were examined by western bolt analysis, with $\beta$-actin as the normalization reference. (A) Representative blot images. (B) Quantification for PI3K. (C) Quantification for Akt. Data are expressed as the mean relative to control \pm standard deviation $(n=3)$. ${ }^{* *} \mathrm{P}<0.01$ vs. control siRNA-transfected cells. PI3K, phosphatidyl inositol 3-kinase; Akt, RAC- $\alpha$ serine/threonine-protein kinase; siRNA, small interfering RNA.

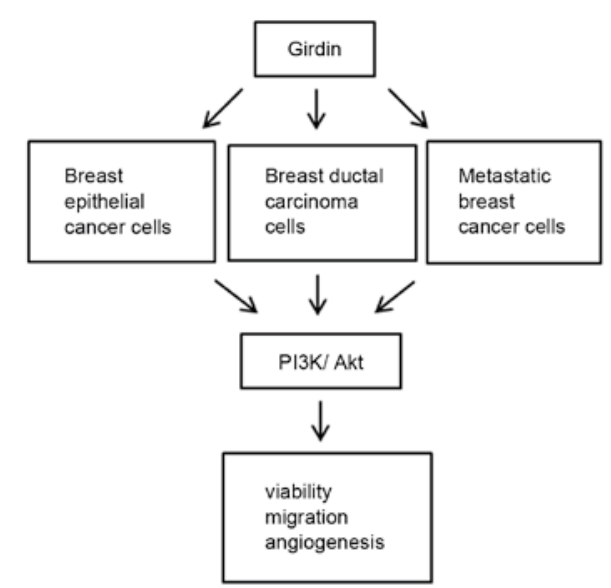

Figure 7. Schematic model describing the potential molecular mechanism of Girdin action in breast cancer cells. Girdin knockdown suppressed cell viability, migration and angiogenesis in the three different breast cancer subtypes examined in the present study (breast epithelial cancer, breast ductal carcinoma and metastatic breast cancer), potentially by downregulating the PI3K/Akt signaling pathway. PI3K, phosphatidyl inositol 3-kinase; Akt, RAC- $\alpha$ serine/threonine-protein kinase. that Girdin is important in combining with G protein (24). Although the present study provides evidence that Girdin may be important in regulating cancer cell viability, migration and angiogenesis, the underlying mechanism remains unclear and requires further investigation in the future. In conclusion, the present study suggested that Girdin may serve as a potential novel target for the development of novel clinical treatments for breast cancer.

\section{Acknowledgements}

The present work was supported by the Heilongjiang Provincial Health and Family Planning Commission (grant no. 2014-358).

\section{References}

1. Sun YW, Chen KY, Kwon CH and Chen KM: CK0403, a 9-aminoacridine, is a potent anti-cancer agent in human breast cancer cells. Mol Med Rep 13: 933-938, 2016.

2. Jemal A, Bray F, Center MM, Ferlay J, Ward E and Forman D: Global cancer statistics. CA Cancer J Clin 61: 69-90, 2011.

3. Perou CM, Sørlie T, Eisen MB, van de Rijn M, Jeffrey SS, Rees CA, Pollack JR, Ross DT, Johnsen H, Akslen LA, et al: Molecular portraits of human breast tumours. Nature 406: 747-752, 2000.

4. Jiang P, Enomoto A, Jijiwa M, Kato T, Hasegawa T, Ishida M, Sato T, Asai N, Murakumo Y and Takahashi M: An actin-binding protein Girdin regulates the motility of breast cancer cells. Cancer Res 68: 1310-1318, 2008.

5. Enomoto A, Murakami H, Asai N, Morone N, Watanabe T, Kawai K, Murakumo Y, Usukura J, Kaibuchi K and Takahashi M: Akt/PKB regulates actin organization and cell motility via Girdin/APE. Dev Cell 9: 389-402, 2005.

6. Enomoto A, Ping J and Takahashi M: Girdin, a novel actin-binding protein and its family of proteins possess versatile functions in the Akt and Wnt signaling pathways. Ann NY Acad Sci 1086: 169-184, 2006.

7. Kitamura T, Asai N, Enomoto A, Maeda K, Kato T, Ishida M, Jiang P, Watanabe T, Usukura J, Kondo T, et al: Regulation of VEGF-mediated angiogenesis by the Akt/PKB substrate Girdin. Nat Cell Biol 10: 329-337, 2008.

8. Cao K, Lu C, Han S, Zou Q, Li J, Xie D, He S, Yu L, Zhou J, Peng X and Cao P: Expression of Girdin in primary hepatocellular carcinoma and its effect on cell proliferation and invasion. Int J Clin Exp Pathol 8: 551-559, 2015.

9. Yuan Z, Feng W, Hong J, Zheng Q, Shuai J and Ge Y: p38MAPK and ERK promote nitric oxide production in cultured human retinal pigmented epithelial cells induced by high concentration glucose. Nitric Oxide 20: 9-15, 2009.

10. Yang L, Shu T, Liang Y, Gu W, Wang C, Song X, Fan C and Wang W: GDC-0152 attenuates the malignant progression of osteosarcoma promoted by ANGPTL2 via PI3K/AKT but not p38MAPK signaling pathway. Int J Oncol 46: 1651-1658, 2015.

11. Laemmli UK: Cleavage of structural proteins during the assembly of the head of bacteriophage T4. Nature 227: 680-685, 1970.

12. Kyhse-Andersen J: Electroblotting of multiple gels: A simple apparatus without buffer tank for rapid transfer of proteins from polyacrylamide to nitrocellulose. J Biochem Biophys Methods 10: 203-209, 1984.

13. Lan T, Wang L, Xu Q, Liu W, Jin H, Mao W, Wang X and Wang X: Growth inhibitory effect of Cucurbitacin E on breast cancer cells. Int J Clin Exp Pathol 6: 1799-1805, 2013.

14. Sorlie T, Tibshirani R, Parker J, Hastie T, Marron JS, Nobel A, Deng S, Johnsen H, Pesich R, Geisler S, et al: Repeated observation of breast tumor subtypes in independent gene expression data sets. Proc Natl Acad Sci USA 100: 8418-8423, 2003.

15. Kim G, Ouzounova M, Quraishi AA, Davis A, Tawakkol N, Clouthier SG, Malik F, Paulson AK, D'Angelo RC, Korkaya S, et al: SOCS3-mediated regulation of inflammatory cytokines in PTEN and p53 inactivated triple negative breast cancer model. Oncogene 34: 671-680, 2015.

16. Weng L, Enomoto A, Ishida-Takagishi M, Asai N and Takahashi M: Girding for migratory cues: Roles of the Akt substrate Girdin in cancer progression and angiogenesis. Cancer Sci 101: 836-842, 2010. 
17. Natsume A, Kato T, Kinjo S, Enomoto A, Toda H, Shimato S, Ohka F, Motomura K, Kondo Y, Miyata T, et al: Girdin maintains the stemness of glioblastoma stem cells. Oncogene 31: 2715-2724, 2012.

18. Ito T, Komeima K, Yasuma T, Enomoto A, Asai N, Asai M, Iwase S, Takahashi M and Terasaki H: Girdin and its phosphorylation dynamically regulate neonatal vascular development and pathological neovascularization in the retina. Am J Pathol 182: 586-596, 2013.

19. Zhang W, Zhang X, Lu H, Matsukura M, Zhao J and Shinohara M Silencing heme oxygenase-1 gene expression in retinal pigment epithelial cells inhibits proliferation, migration and tube formation of cocultured endothelial cells. Biochem Biophys Res Commun 434: 492-497, 2013.

20. Cantley LC: The phosphoinositide 3-kinase pathway. Sicience 296: 1655-1657, 2002.
21. Vivanco I and Sawyers CL: The phosphatidylonositol 3-kinase-AKT pathway in human cancer. Nat Rev Cancer 2: 489-501, 2002.

22. Gallia GL, Tyler BM, Hann CL, Siu IM, Giranda VL, Vescovi AL, Brem H and Riggins GJ: Inhibition of Akt inhibits growth of glioblastoma and glioblastoma stem-like cells. Mol Cancer Ther 8: 386-393, 2009.

23. Woodgett JR: Recent advances in the protein kinase B signaling pathway. Curr Opin Cell Biol 17: 150-157, 2005.

24. Le-Niculescu H, Niesman I, Fischer T, DeVries L and Farquhar MG: Identification and characterization of GIV, a novel Galpha i/s-interacting protein found on COPI, endoplasmic reticulum-Golgi transport vesicles. J Biol Chem 280: 22012-22020, 2005. 